International Journal of

Environmental Research and

Public Health

ISSN 1660-4601

www.mdpi.com/journal/ijerph

Article

\title{
Association between Chronic Arsenic Exposure and Nutritional Status among the Women of Child Bearing Age: A Case-Control Study in Bangladesh
}

\author{
Abul H. Milton ${ }^{1}{ }^{*}$, S. M. Shahidullah ${ }^{2}$, Wayne Smith ${ }^{1}$, Kazi S. Hossain ${ }^{3}$, Ziaul Hasan ${ }^{2}$ and \\ Kazi T. Ahmed ${ }^{2}$
}

1 Centre for Clinical Epidemiology \& Biostatistics (CCEB), School of Medicine, The University of Newcastle, University Drive, Callaghan, NSW 2308, Australia;

E-Mail: WSMIT@doh.health.nsw.gov.au (W.S.)

2 NGO Forum for Drinking Water Supply \& Sanitation, 4/6, Block-E, Lalmatia,Dhaka-1207, Bangladesh; E-Mails: wqtl@ngof.org (S.M.S); ziahasan@ hotmail.com (Z.H.); tanvir@ngof.org (K.T.A.)

3 Centre for Health and Development (CHAD), Ramdia, Bethuria, Kashiani, Gopalgonj, Bangladesh; E-Mail: h_d25@hotmail.com (K.S.H.)

* Author to whom correspondence should be addressed; E-Mail: milton.hasnat@ newcastle.edu.au; Tel.: +61-2-4913-8200 (w); Fax: +61-2-4913-8148.

Received: 14 May 2010; in revised form: 13 June 2010 / Accepted: 30 June 2010 /

Published: 2 July 2010

\begin{abstract}
The role of nutritional factors in arsenic metabolism and toxicity is yet to be fully elucidated. A low protein diet results in decreased excretion of DMA and increased tissue retention of arsenic in experimental studies. Malnourished women carry a higher risk of adverse pregnancy outcomes. Chronic exposure to high arsenic ( $>50 \mu \mathrm{g} / \mathrm{L})$ through drinking water also increases the risk of adverse pregnancy outcomes. The synergistic effects (if any) of malnutrition and chronic arsenic exposure may worsen the adverse pregnancy outcomes. This population based case control study reports the association between chronic arsenic exposure and nutritional status among the rural women in Bangladesh. 348 cases (BMI < 18.5) and 360 controls (BMI 18.5-24.99) were recruited from a baseline survey conducted among 2,341 women. An excess risk for malnutrition was observed among the participants chronically exposed to higher concentrations of arsenic in drinking water after adjusting for potential confounders such as participant's age,
\end{abstract}


religion, education, monthly household income and history of oral contraceptive pills. Women exposed to arsenic $>50 \mu \mathrm{g} / \mathrm{L}$ were at 1.9 times (Odds Ratio $=1.9,95 \%$ $\mathrm{CI}=1.1-3.6)$ increased risk of malnutrition compared to unexposed. The findings of this study suggest that chronic arsenic exposure is likely to contribute to poor nutritional status among women of $20-45$ years.

Keywords: arsenic; nutritional status; reproductive aged women

\section{Introduction}

Arsenic contamination of drinking water is a public health problem in Bangladesh [1]. Extent of the drinking water arsenic contamination is unprecedented in rural areas of the country. Approximately one-third of the hand tube wells in Bangladesh contain arsenic more than $10 \mu \mathrm{g} / \mathrm{L}$, the recommended level of arsenic in drinking water by the WHO [2]. Chronic exposure to arsenic has the potentials to cause wide ranges of carcinogenic and non-carcinogenic health effects such as cancer of the skin and internal organs, diabetes mellitus, hypertension, and respiratory conditions [3-10]. Among the non-carcinogenic effects, chronic arsenic exposure has also been reported to increase the risk of foetal and infant deaths [11-16].

Drinking water in Bangladesh contains mostly inorganic arsenic. Inorganic arsenic, once ingested is excreted through urine in human [17]. A series of reduction and oxidation methylation reactions occur in liver to form monomethylarsonic acid (MMA) and dimethylarsinic acid (DMA) [18]. Endogenous thiols probably play a critical role in the metabolic conversion of As (III) and As (V) species. Glutathion is likely to act as a reducing agent for converting As (V) species into As (III), which can then accept a methyl group from S-Adenosylmethionine (SAM) to produce the methyl arsenic (V) species [19]. Diet containing methionine, choline, folate, and other nutrients may be the source of this methyl group from SAM. However, the role of nutritional factors on arsenic metabolism and toxicity is yet to be fully explored.

Limited studies have indicated that poor nutritional status may increase the risk of arsenic related health effects [20-24]. Participants with poor nutritional status (weight below $80 \%$ of the standard body weight for their age and sex) were reported from West Bengal, India to have an overall 1.6 fold-increase (for males $=1.5$, females $=2.1$ ) in the prevalence of keratoses, suggesting that malnutrition may increase the susceptibility for arsenic toxicity [22]. Arsenic affected people of south western Taiwan and the Antofagasta region in northern Chile were reported to have a low socio-economic status and poor nutritional status $[20,21,23,24]$. Experimental studies have shown that rabbits fed diets containing low methionine, choline, or proteins have a decrease in arsenic methylation and an increase in tissue retention of arsenic, especially in the liver [25]. Decrease in urinary excretion of dimethyl arsinic acid (DMA) was also observed in another study where mice were fed a choline-deficient diet [26]. Lower Body mass index (BMI) was reported among the arsenicosis patients compared to the unexposed population in a previous study in Bangladesh [27]. In a recent study in Bangladesh, Heck et al observed that higher intakes of protein, methionine, and cysteine were associetd with 10-15\% greater total urinary arsenic excretion, after adjusting for total energy intake, 
body weight, sex, age, tobacco use, and intake of some other nutrients [28]. However, a study from Atacameño in northern Chile reported no evidence of malnutrition among individuals with arsenic induced skin lesions [29]. Each of the families with arsenic-induced skin lesions consumed many vegetables, including carrots, everyday. This might be due to that high carotene intake and vitamin $\mathrm{A}$ do not prevent arsenic-induced skin lesions.

Malnutrition is highly prevalent in rural Bangladesh [27]. Malnourished women are likely to have higher risk of adverse pregnancy outcomes. Malnutrition during pregnancy may increase the risk of intra-uterine growth, low birth weight baby, stunting, severe wasting and foetal death [30,31]. Experimental studies on ewes and rats have shown that malnutrition during pregnancy resulted in modifications of embryo development leading to abnormalities of the offspring in late gestation and postnatal periods [32-34]. Chronic exposure to arsenic through drinking water also increases the risk of adverse pregnancy outcomes [11-16]. The combined effects of malnutrition and chronic arsenic exposure may worsen the adverse pregnancy outcomes. Therefore, the purpose of this case-control study was to determine the association between chronic arsenic exposure and nutritional status of the women of child bearing age in rural Bangladesh.

\section{Methods}

\subsection{Study Area}

The study was conducted in all the villages of the Nezamkandi union, Kashiani upazila (subdistrict) of the Gopalgonj district. The study area is a known arsenic contaminated area, although no individuals with visible arsenical skin lesions were observed from this area. The area is approximately $200 \mathrm{~km}$ south from Dhaka, the capital city of Bangladesh. The study was conducted during January 2006 to December 2008.

\subsection{Selection of Cases and Controls}

In this population based case-control study, 365 cases and 365 controls were recruited. A total of 335 cases and 335 controls with a case: control ratio of 1:1 are sufficient to demonstrate an odds ratio of 1.5 at a level of $95 \%$ confidence and $80 \%$ power in the study population where $30 \%$ of the controls are chronically exposed to arsenic concentration more than $50 \mu \mathrm{g} / \mathrm{L}$. We recruited extra 30 cases and 30 controls to accommodate non-response, unavailability and refusal of the participants.

Initially a baseline survey was carried out among 2341 eligible women [35]. Eligible participants were women aged 20-45 years living in the study area for at least six months. Of these 2,341, 798 $(34 \%)$ women were found as malnourished (BMI < 18.5). Currently pregnant women were not included in the baseline study. Three respondents were excluded from the analysis of baseline data as their interview schedules were incomplete. Three hundred sixty five cases and 365 controls were randomly selected from the sampling frame of cases $(\mathrm{N}=798)$ and controls $(\mathrm{N}=1,543)$. Women with a BMI < 18.5, aged between 20-45 years, have been drinking water from a tube well and have been a resident of the study area for the preceding six months were recruited as cases. Women having a $\mathrm{BMI}>18.5$ were recruited in the study as controls, other inclusion criteria for them were same as the cases. Pregnant women and women suffering from any chronic illness were excluded from the study. 
Of these cases and controls, 348 cases and 360 controls were included in the final analysis as rest of the participants was excluded for incomplete data. A total of 242 tube wells were used by the study participants. We obtained ethical approval from the Health Human Research Ethics Committee of The University of Newcastle, NSW, Australia and The Bangladesh Medical Research Council, Bangladesh.

\subsection{Data Collection}

A structured pretested interviewer-administered questionnaire was used to collect information from cases and controls on sociodemographic variables including household's total monthly income, drinking water history, nutritional status and pregnancy related history. Six trained interviewers (three men and three women) administered the questionnaires by face-to-face interview. Standing height and weight of each participant were measured with the subjects wearing light clothes and not wearing shoes. Height was measured in centimetres using a locally made wooden measuring board with a metal measurement tape attached. Weight was measured in kilograms using bathroom scales that were calibrated daily and zeroed before each measurement. All measurements were made according to WHO procedures [36].

\subsection{Outcome Definition}

Individual nutritional status of the study women was assessed using body mass index (BMI), calculated as [weight $(\mathrm{kg})] /\left[\right.$ height $\left.(\mathrm{m})^{2}\right]$. BMI was interpreted as malnourished when $<18.5$, normal if ranging between 18.5 and 24.99 and overweighted if it exceeds 24.99 [37]. Cases and controls were those women had a BMI $<18.5$ and $\mathrm{BMI}>18.5$, respectively.

\subsection{Exposure Assessment}

A single tube well water measurement was used to characterise chronic arsenic exposure for each study participant. We calculated duration of individual arsenic exposure from the period of use of the particular tube well. Water samples were collected, transferred and preserved following standard procedures [38]. All these water samples were analysed for arsenic at the NGO Forum for Drinking Water Supply and Sanitation's water quality testing laboratory in Dhaka using flow-injection hydride generation atomic absorption spectrometry method [38]. The minimum detection level for arsenic is $3 \mu \mathrm{g} / \mathrm{L}$ in this method.

\subsection{Statistical Analysis}

Data analysis was carried out using Stata 9.0 statistical software (StataCorp LP, TX, USA). Baseline characteristics were compared among cases and controls using chi-square and t-test as appropriate.

Logistic regression analysis was done to calculate odds ratios (ORs) and 95\% confidence intervals (CIs) for each outcome, initially adjusted for the potential confounders of participant's age, education, religion, marital status, monthly total household income, type of roof, age at menstruation, duration of menstruation, age at marriage, history of oral contraceptives, and total number of pregnancy. In the final logistic regression models, we only included those variables found to be significant at $25 \%$ 
$(\mathrm{p}<0.25)$ level in the initial models to accommodate more explanatory variables in the final model and to reduce type II error.

Arsenic concentration was categorised as $\leq 50 \mu \mathrm{g} / \mathrm{L}$ and $>50 \mu \mathrm{g} / \mathrm{L}$, (and subcategorised as) 51-100 and $>100 \mu \mathrm{g} / \mathrm{L}$; for each, duration of exposure was categorised as up to 10 years and more than 10 years. Confidence intervals from the final analysis for cases and controls were based on standard errors adjusted for clustering of outcomes among women using the same tube well using Huber/White robust 'sandwich' estimator of variance, which is based on the within-cluster correlation observed in the data.

\section{Results and Discussion}

Table 1. Baseline characteristics of the cases and controls *.

\begin{tabular}{|l|c|c|c|}
\hline Variable & Cases $(\mathbf{n}=\mathbf{3 4 8})$ & Controls $(\mathbf{n}=\mathbf{3 6 0})$ & $\boldsymbol{p}$ \\
\hline Age (years); mean $\pm \mathrm{sd}$ & $29.9 \pm 7.8$ & $30.4 \pm 8.1$ & 0.32 \\
\hline Occupation & & & \\
Housewife & 94.8 & 92.5 & 0.23 \\
Others & 5.2 & 7.5 & \\
\hline Educational status & & & \\
No formal education & 24.7 & 23.2 & 0.16 \\
Primary & 43.1 & 47.2 & \\
Secondary or above & 32.2 & 29.6 & \\
\hline Roof type & & & \\
Tin & 94.5 & 94.7 & 0.27 \\
Others & 5.5 & 5.3 & \\
\hline Total monthly household income (US \$); mean \pm sd & $47.3 \pm 37.7$ & $55.1 \pm 46.5$ & 0.02 \\
\hline Religion & & & \\
Muslim & 74.7 & 68.3 & \\
Others & 25.3 & 31.7 & 0.06 \\
\hline Age at menstruation (years); mean \pm sd & $12.6 \pm 0.79$ & $12.6 \pm 0.79$ & 0.46 \\
\hline Duration of menstruation (days); mean \pm sd & $3.8 \pm 1.4$ & $3.7 \pm 1.2$ & 0.58 \\
\hline Age at marriage (years); mean \pm sd & $16.1 \pm 2.2$ & $16.1 \pm 1.8$ & 0.92 \\
\hline Total number of pregnancy/woman; mean \pm sd & $3.6 \pm 2.4$ & $3.6 \pm 2.1$ & 0.92 \\
\hline Arsenic concentration $(\mu \mathrm{gg} / \mathrm{L}) ;$ & & & \\
0-50 & 24.1 & 36.4 & \\
$>50-100$ & 15.6 & 14.7 & $<0.01$ \\
$>100$ & 60.3 & 48.9 & \\
\hline Duration of arsenic exposure (years); mean \pm sd & $1.51 \pm 0.05$ & $1.51 \pm 0.05$ & 0.13 \\
\hline Height (metres); mean \pm sd & $17.1 \pm 0.9$ & $20.9 \pm 1.8$ & $<0.01$ \\
\hline Weight (kilogram); mean \pm sd & & & \\
\hline Body Mass Index (BMI); mean \pm sd & & & \\
\hline & & & \\
\hline
\end{tabular}

* Results are expressed as percent, unless otherwise indicated.

Results regarding the association of arsenic concentration and nutritional status are given in Table 2.

An increased risk of malnutrition is observed for arsenic over $50 \mu \mathrm{g} / \mathrm{L}$. 
Table 1 presents the baseline characteristics, arsenic exposure and nutritional status of the cases and controls. Cases are similar to the controls with respect to its baseline characteristics except total monthly household income, arsenic concentrations and body weight.

Table 2. Association between arsenic concentrations with nutritional status of the women of reproductive age*.

\begin{tabular}{|c|c|c|c|c|}
\hline $\begin{array}{c}\text { Arsenic concentration } \\
(\boldsymbol{\mu g} / \mathbf{L})\end{array}$ & $\begin{array}{c}\text { Cases }(\mathbf{n}=\mathbf{3 4 8}) \\
(\mathbf{B M I}<\mathbf{1 8 . 5})\end{array}$ & $\begin{array}{c}\text { Controls }(\mathbf{n}=\mathbf{3 6 0}) \\
(\mathbf{B M I}>\mathbf{1 8 . 5})\end{array}$ & Odds ratio (OR) & $\mathbf{9 5 \%} \mathbf{C I}$ \\
\hline$\leq 50 \dagger$ & 84 & 131 & 1.0 & - \\
\hline$>50$ & 264 & 229 & 1.9 & $1.1-3.6$ \\
\hline$>50-100 \dagger$ & 54 & 53 & 1.9 & $0.8-4.3$ \\
\hline$>100$ & 210 & 176 & 2 & $1.1-3.6$ \\
\hline
\end{tabular}

* Ajusted for age, religion, participant's education, monthly income and history of oral contraceptive pills.

$\$$ Adjuste for age, religion, monthly income and history of oral contraceptive pills.

$\dagger$ Referene category.

The combined effects of arsenic concentration and duration of arsenic exposure on nutritional status are presented in Table 3. For arsenic concentration of $100 \mu \mathrm{g} / \mathrm{L}$ with an exposure of $\leq 10$ years, the risk estimate for malnutrition is high. The reference group is those who had concentrations not exceeding $50 \mu \mathrm{g} / \mathrm{L}$ regardless of the duration of exposure.

Table 3. Association between arsenic concentrations and duration of exposure with nutritional status of the women of reproductive age*.

\begin{tabular}{|c|c|c|c|c|c|}
\hline $\begin{array}{c}\text { Duration of As } \\
\text { exposure }\end{array}$ & As $($ in $\boldsymbol{\mu g} / \mathbf{L})$ & $\begin{array}{c}\text { Cases* }(\mathbf{n}=\mathbf{3 4 2}) \\
(\mathbf{B M I}<\mathbf{1 8 . 5})\end{array}$ & $\begin{array}{c}\text { Controls }(\mathbf{n}=\mathbf{3 6 0}) \\
(\mathbf{B M I} \mathbf{~ 1 8 . 5})\end{array}$ & $\begin{array}{c}\text { Odds Ratio } \\
(\mathbf{O R})\end{array}$ & 95\% CI \\
\hline Any duration $\dagger$ & 50 & 78 & 131 & 1 & - \\
\hline$\leq 10$ years & $>50-100$ & 44 & 38 & 1.9 & $0.7-5.5$ \\
\hline & $>100$ & 156 & 132 & 2.2 & $1.1-4.3$ \\
\hline$>10$ years & $>50-100$ & 10 & 15 & 1.9 & $0.7-5.2$ \\
\hline & $>100$ & 54 & 44 & 1.7 & $0.8-3.3$ \\
\hline
\end{tabular}

* missing $=6$.

* Adjusted for age, religion, type of roof, participant's education, monthly income and history of oral contraceptive pills.

$\dagger$ Reference category.

In this study, we assessed the risk of malnutrition among the women of reproductive age i.e., 20-45 years at several concentrations of arsenic in drinking water in rural Bangladesh. The findings suggest an association between chronic arsenic exposure through drinking water and malnutrition. An overall 1.9 fold $(95 \% \mathrm{CI}=1.1-3.6)$ increase in poor nutritional status was observed among the arsenic exposed women compared to women who were not exposed to arsenic more than $50 \mu \mathrm{g} / \mathrm{L}$.

Risks were generally higher for those exposed to arsenic more than $100 \mu \mathrm{g} / \mathrm{L}$. Excess risk was observed among the women who were exposed to arsenic more than $100 \mu \mathrm{g} / \mathrm{L}$ and for $\leq 10$ years. 
Women exposed to arsenic more than $50 \mu \mathrm{g} / \mathrm{L}$ for more than 10 years showed weaker association. This may be due to inaccurate self reporting of arsenic exposure duration by the participants.

Similar observations have been reported from West Bengal, India and Taiwan. In an arsenic-exposed population in West Bengal body weight was negatively associated with the occurrence of keratosis [22] and in Taiwan vascular effects (blackfoot-disease) were associated with undernourishment (high intake of sweet potatoes, low intake of rice and vegetables) [39]. In Taiwan, a low serum $\beta$-carotene concentration was associated with a higher prevalence of arsenic-related skin-cancer [40] and ischemic heart disease [41].

It is not clear how the nutritional status of an individual influences the arsenic metabolism and toxicity process. Experimental studies in rabbits have shown that diets with low amount of methionine, choline or proteins reduced the urinary excretion of DMA, an end product of methylation [25]. Whether it is also applicable for humans is not known. Zinc has been suggested to influence arsenic toxicity [5] and mice fed a selenium-deficient diet showed a slower elimination of arsenic than selenium-sufficient mice [42]. Also, dietary selenium supplementation was found to prevent cytotoxic effects of arsenic mice in vivo [43]. Given that a deficiency in folate and vitamin B12 might lead to decreased levels of S-adenosylmethyltransferase [44], it may also result in decreased methylation of arsenic. Indeed, folic acid was found to protect mouse embryo fibroblasts against cytotoxicity of arsenic [45].

Chronic arsenic exposure has been reported to be associated with human adverse pregnancy outcomes in a few studies [11-14,16]. Animal model experimentation have also shown the toxicity of several forms of arsenic on pregnancy outcomes including malformations [46]. Recent studies reported that arsenic crosses the human placenta [47], although more than 90 percent of the arsenic in plasma and urine was in the form of dimethylarsenic acid indicating an increase in the methylation of arsenic during pregnancy. Maternal toxicity has also found to be associated with the adverse developmental effects of arsenic exposure. There are instances that the maternal toxicity is the causative factor in abnormal development of the embryos [48]. This is probably due to induction of metallothionein in the maternal liver that leads to a systemic redistribution of zinc and a transitory, but developmentally adverse zinc deficiency. These effects were produced in pregnant rat by arsenate. Exposure to arsenic also exerted direct adverse effects on explanted rodent embryos exposed to arsenic in the absence of the maternal system. However, a poor correlation was found on maternal and developmental toxicity relationship in an extensive literature analysis [49]. Therefore, arsenic is likely to have direct toxic effects on embryos in vivo, but its effects might be exacerbated by external toxicity [4]. Therefore, combined effects of malnutrition and chronic arsenic exposure may worsen the reproductive health of the women of particular age group.

To the best of our knowledge, this is the first study carried out to determine the effect of chronic arsenic exposure on the nutritional status of the women of reproductive age. None of the study participants had visible arsenical skin lesions. Therefore, the observed risk of malnutrition in this study is likely to be the effect of chronic arsenic exposure than to be the consequence of arsenical skin lesions.

We used BMI as the indicator of nutritional status in this study. Of the anthropometric indices, body mass index is considered to be more nutritionally than genetically related [50]. Thus it is appropriate to use BMI as an indicator of the adult nutritional status. However, body mass index is not the only 
indicator for measuring nutritional status. So, further studies including detail assessment of nutritional status together with evaluation of dietary intake and blood studies is required to understand the dynamics of malnutrition.

In case-control studies, exposure measurement remains as an important issue. In our study, we only collected water sample from one tube well for each participant's exposure measurement. This single water measurement may not represent the historical arsenic exposure over time. However, due to absence of any reliable information on past exposure, it was essential to assume that arsenic concentrations from the tube wells had been relatively constant over time. The historical consistency of arsenic concentration is of particular concern with shallow ground water, which might be subject to greater fluctuation than water from a deeper well [5]. However, any fluctuation of arsenic concentrations is likely to affect the cases and controls equally. Interviewer bias is less likely because the interviewers were unaware of the arsenic concentration levels of the participant's usual drinking water source. Nevertheless, strength of this study is the study design, availability of individual arsenic exposure data, BMI and determination of risk at different arsenic concentration levels.

\section{Conclusions}

The findings of this study add to the evidence that chronic arsenic exposure is likely to contribute to poor nutritional status among women of 20-45 years.

\section{Acknowledgements}

The research was funded by the International Atomic Energy Agency, Austria as a coordinated research project (CRP contract number: 13243/RO).

\section{Conflict of Interests}

We declare that we have no conflict of interest.

\section{References}

1. Smith, A.H.; Lingas, E.O.; Rahman, M. Contamination of drinking-water by arsenic in Bangladesh: A public health emergency. Bull. World Health Organ. 2000, 78, 1093-1103.

2. Kinniburgh, D.G.; Smedley, P.L.E. Arsenic Contamination of Groundwater in Bangladesh; British Geological Survey (BGS), Department for International Development (DFID), Government of the People's Republic of Bangladesh, Ministry of Local Government, Rural Development and Cooperatives, Department of Public Health Engineering (DPHE): Dhaka, Bangladesh, 2001; p. 2.

3. IARC Monographs on the Evaluation of the Carcinogenic Risk of Chemicals to Humans: Some Metals and Metallic Compounds; International Agency for Research on Cancer (IARC): Lyon, France, 1980; pp. 39-141.

4. Arsenic in Drinking Water; National Research Council: Washington, DC, USA, 1999.

5. Arsenic in Drinking Water 2001 Update; National Research Council: Washington, DC, USA, 2001. 
6. Milton, A.H.; Hasan, Z.; Rahman, A.; Rahman, M. Chronic arsenic poisoning and respiratory effects in Bangladesh. J. Occup. Health 2001, 43, 136-140.

7. Milton, A.H.; Rahman, M. Environmental pollution and skin involvement patern of chronic arsenicosis in Bangaldesh. J. Occup. Health 1999, 41, 207-208.

8. Rahman, M.; Tondel, M.; Ahmad, S.A.; Axelson, O. Diabetes mellitus associated with arsenic exposure in Bangladesh. Am. J. Epidemiol. 1998, 148, 198-203.

9. Rahman, M.; Tondel, M.; Ahmad, S.A.; Chowdhury, I.A.; Faruquee, M.H.; Axelson, O. Hypertension and arsenic exposure in Bangladesh. Hypertension 1999, 33, 74-78.

10. Mazumder, D.N.; Haque, R.; Ghosh, N.; De, B.K.; Santra, A.; Chakraborti, D.; Smith, A.H. Arsenic in drinking water and the prevalence of respiratory effects in West Bengal, India. Int. J. Epidemiol. 2000, 29, 1047-1052.

11. Ahmad, S.A.; Sayed, M.H.; Barua, S.; Khan, M.H.; Faruquee, M.H.; Jalil, A.; Hadi, S.A.; Talukder, H.K. Arsenic in drinking water and pregnancy outcomes. Environ. Health. Perspect. 2001, 109, 629-631.

12. Hopenhayn-Rich, C.; Browning, S.R.; Hertz-Picciotto, I.; Ferreccio, C.; Peralta, C.; Gibb, H. Chronic arsenic exposure and risk of infant mortality in two areas of Chile. Environ. Health Perspect. 2000, 108, 667-673.

13. Nordstrom, S.; Beckman, L.; Nordenson, I. Occupational and environmental risks in and around a smelter in northern Sweden. III. Frequencies of spontaneous abortion. Hereditas 1978, 88, 51-54.

14. Borzsonyi, M.; Bereczky, A.; Rudnai, P.; Csanady, M.; Horvath, A. Epidemiological studies on human subjects exposed to arsenic in drinking water in southeast Hungary. Arch. Toxicol. 1992, $66,77-78$.

15. Yang, C.Y.; Chang, C.C.; Tsai, S.S.; Chuang, H.Y.; Ho, C.K.; Wu, T.N. Arsenic in drinking water and adverse pregnancy outcome in an arseniasis-endemic area in northeastern Taiwan. Environ. Res. 2003, 91, 29-34.

16. Milton, A.H.; Smith, W.; Rahman, B.; Hasan, Z.; Kulsum, U.; Dear, K.; Rakibuddin, M.; Ali, A. Chronic arsenic exposure and adverse pregnancy outcomes in bangladesh. Epidemiology 2005, $16,82-86$.

17. Buchet, J.P.; Lauwerys, R. Evaluation of Exposure to Inorganic Arsenic in man. In Analytical Techniques for Heavy Metals in Biological Fluids; Facchetti, S., Ed.; Elsevier: Amsterdam, The Netherland, 1983; pp. 75-90.

18. Kitchin, K.T. Recent advances in arsenic carcinogenesis: Modes of action, animal model systems, and methylated arsenic metabolites. Toxicol. Appl. Pharmacol. 2001, 172, 249-261.

19. Cullen, W.R.; Reimer, K.J. Arsenic speciation in the environment. Chem. Rev. 1989, 89, 713-764.

20. Borgono, J.M.; Vicent, P.; Venturino, H.; Infante, A. Arsenic in the drinking water of the city of Antofagasta: Epidemiological and clinical study before and after the installation of a treatment plant. Environ. Health Perspect. 1977, 19, 103-105.

21. Hsueh, Y.M.; Cheng, G.S.; Wu, M.M.; Yu, H.S.; Kuo, T.L.; Chen, C.J. Multiple risk factors associated with arsenic-induced skin cancer: effects of chronic liver disease and malnutritional status. Br. J. Cancer 1995, 71, 109-114. 
22. Mazumder, D.N.; Haque, R.; Ghosh, N.; De, B.K.; Santra, A.; Chakraborty, D.; Smith, A.H. Arsenic levels in drinking water and the prevalence of skin lesions in West Bengal, India. Int. J. Epidemiol. 1998, 27, 871-877.

23. Tseng, W.P. Effects and dose-response relationships of skin cancer and blackfoot disease with arsenic. Environ. Health. Perspect. 1977, 19, 109-119.

24. Zaldivar, R. Ecological investigations on arsenic dietary intake and endemic chronic poisoning in man: Dose-response curve. Zentralbl Bakteriol [Orig B] 1977, 164, 481-484.

25. Vahter, M.; Marafante, E. Effects of low dietary intake of methionine, choline or proteins on the biotransformation of arsenite in the rabbit. Toxicol. Lett. 1987, 37, 41-46.

26. Tice, R.R.; Yager, J.W.; Andrews, P.; Crecelius, E. Effect of hepatic methyl donor status on urinary excretion and DNA damage in $\mathrm{B} 6 \mathrm{C} 3 \mathrm{~F} 1$ mice treated with sodium arsenite. Mutat. Res. 1997, 386, 315-334.

27. Milton, A.H.; Hasan, Z.; Shahidullah, S.M.; Sharmin, S.; Jakariya, M.D.; Rahman, M.; Dear, K.; Smith, W. Association between nutritional status and arsenicosis due to chronic arsenic exposure in Bangladesh. Int. J. Environ. Health Res. 2004, 14, 99-108.

28. Heck, J.E.; Nieves, J.W.; Chen, Y.; Parvez, F.; Brandt-Rauf, P.W.; Graziano, J.H.; Slavkovich, V.; Howe, G.R.; Ahsan, H. Dietary intake of methionine, cysteine, and protein and urinary arsenic excretion in Bangladesh. Environ. Health Perspect. 2009, 117, 99-104.

29. Smith, A.H.; Arroyo, A.P.; Mazumder, D.N.; Kosnett, M.J.; Hernandez, A.L.; Beeris, M.; Smith, M.M.; Moore, L.E. Arsenic-induced skin lesions among Atacameno people in Northern Chile despite good nutrition and centuries of exposure. Environ. Health Perspect. 2000, 108, 617-620.

30. Hally, S.S. Nutrition in reproductive health. J. Nurse Midwifery 1998, 43, 459-470.

31. Khan, S. Importance of nutrition for female population of reproductive age. J. Pak. Med. Assoc. 1983, 33, 264-265.

32. Bloomfield, F.H.; Oliver, M.H.; Hawkins, P.; Holloway, A.C.; Campbell, M.; Gluckman, P.D.; Harding, J.E.; Challis, J.R. Periconceptional undernutrition in sheep accelerates maturation of the fetal hypothalamic-pituitary-adrenal axis in late gestation. Endocrinology 2004, 145, 4278-4285.

33. Fleming, T.P.; Kwong, W.Y.; Porter, R.; Ursell, E.; Fesenko, I.; Wilkins, A.; Miller, D.J.; Watkins, A.J.; Eckert, J.J. The embryo and its future. Biol. Reprod. 2004, 71, 1046-1054.

34. Kwong, W.Y.; Wild, A.E.; Roberts, P.; Willis, A.C.; Fleming, T.P. Maternal undernutrition during the preimplantation period of rat development causes blastocyst abnormalities and programming of postnatal hypertension. Development 2000, 127, 4195-4202.

35. Milton, A.H.; Smith, W.; Rahman, B.; Ahmed, B.; Shahidullah, S.M.; Hossain, Z.; Hasan, Z.; Sharmin, S. Prevalence and determinants of malnutrition among reproductive aged women of rural Bangladesh. Asia Pac. J. Public Health 2010, 22, 110-117.

36. Jelliffe, D.B. The Assessment of Nutritional Status of the Community; WHO: Geneva, Switzerland, 1966.

37. Shetty, P.S. Body Mass Index, a Measurement of Chronic Energy Deficiency in Adults; FAO: Rome, Italy, 1994.

38. Standard Methods for the Examination of Water and Wastewater, 19th ed.; Eaton, A.D., Clesceri, L.S., Greenberg, A.E., Eds.; American Public Health Association, American Water Works Association, Water Environment Federation: Washington, DC, USA, 1995. 
39. Chen, C.J.; Wu, M.M.; Lee, S.S.; Wang, J.D.; Cheng, S.H.; Wu, H.Y. Atherogenicity and carcinogenicity of high-arsenic artesian well water. Multiple risk factors and related malignant neoplasms of blackfoot disease. Arteriosclerosis 1988, 8, 452-460.

40. Hsueh, Y.M.; Chiou, H.Y.; Huang, Y.L.; Wu, W.L.; Huang, C.C.; Yang, M.H.; Lue, L.C.; Chen, G.S.; Chen, C.J. Serum beta-carotene level, arsenic methylation capability, and incidence of skin cancer. Cancer Epidemiol. Biomarkers Prev. 1997, 6, 589-596.

41. Hsueh, Y.M.; Huang, Y.L.; Huang, C.C.; Wu, W.L.; Chen, H.M.; Yang, M.H.; Lue, L.C.; Chen, C.J. Urinary levels of inorganic and organic arsenic metabolites among residents in an arseniasis-hyperendemic area in Taiwan. J. Toxicol. Environ. Health A 1998, 54, 431-444.

42. Kenyon, E.M.; Hughes, M.F.; Levander, O.A. Influence of dietary selenium on the disposition of arsenate in the female B6C3F1 mouse. J. Toxicol. Environ. Health 1997, 51, 279-299.

43. Biswas, S.; Talukder, G.; Sharma, A. Prevention of cytotoxic effects of arsenic by short-term dietary supplementation with selenium in mice in vivo. Mutat. Res. 1999, 441, 155-160.

44. Newman, P.E. Can reduced folic acid and vitamin B12 levels cause deficient DNA methylation producing mutations which initiate atherosclerosis? Med. Hypotheses 1999, 53, 421-424.

45. Ruan, Y.; Peterson, M.H.; Wauson, E.M.; Waes, J.G.; Finnell, R.H.; Vorce, R.L. Folic acid protects SWV/Fnn embryo fibroblasts against arsenic toxicity. Toxicol. Lett. 2000, 117, 129-137.

46. Nemec, M.D.; Holson, J.F.; Farr, C.H.; Hood, R.D. Developmental toxicity assessment of arsenic acid in mice and rabbits. Reprod. Toxicol. 1998, 12, 647-658.

47. Concha, G.; Vogler, G.; Lezcano, D.; Nermell, B.; Vahter, M. Exposure to inorganic arsenic metabolites during early human development. Toxicol. Sci. 1998, 44, 185-190.

48. Daston, G.P. Relationship between Maternal and Developmental Toxicity. In Developmental Toxicology, 2nd ed.; Kimmel, C.A., Bulke-Sam, J., Eds.; Raven Press: New York, NY, USA, 1994.

49. Golub, M.S. Maternal toxicity and the identification of inorganic arsenic as a developmental toxicant. Reprod. Toxicol. 1994, 8, 283-295.

50. Khongsdier, E.M. Body mass index of adult males in 12 populations of northeast india. Ann. Hum. Biol. 2001, 28, 374-383.

(C) 2010 by the authors; licensee MDPI, Basel, Switzerland. This article is an Open Access article distributed under the terms and conditions of the Creative Commons Attribution license (http://creativecommons.org/licenses/by/3.0/). 